\title{
KOCKÁZATELEMZÉS A VÁLLALATI PÉNZÜGYI MODELLEZÉSBEN
}

Juhász Péter

A vállalati pénzügyekben alkalmazott modellek jellemzően a jövővel kapcsolatos tudásunk csupán egyetlen részletét, a várható értékeket képesek felhasználni, emiatt a kapott végeredményekben már nem jelenik meg a bemenő paraméterek értékeivel kapcsolatos bizonytalanság. Bár többféle eszköz is rendelkezésünkre áll ahhoz, hogy a kényszerüségből eltüntetett bizonytalanságot az eredmények bemutatásakor mégis éreztetni tudjuk a döntéshozóval, gyakoriak e folyamatban és a kapott kimenetek értelmezésében a félreértések és hibák. E cikk a kockázatelemzési eszköztár áttekintésekor ezek feltárására koncentrál, és bemutatja azt is, hogy a modellezési folyamat kimenetelét milyen más kockázati tényezők befolyásolják. Az irodalom áttekintése alapján úgy látszik, hogy a különféle kockázatok között egyfajta átváltás létezik: az elméletileg pontosabb modellek érzékenyebbek lehetnek a bemenő paraméterek becslési hibáira, és sokkal komolyabb elvárásokat támasztanak a modellezőkkel szemben is.

JEL-kódok: C6, D8, G17, G32

Kulcsszavak: érzékenységvizsgálat, forgatókönyv-elemzés, Monte-Carlo-szimuláció, értékelés

A vállalati pénzügyi döntések a jövővel kapcsolatos információkat igényelnek, azonban ezen információk a legtöbbször igen távol állnak a bizonyosságtól. Emiatt különféle elörejelzésekre, becslésekre támaszkodhatunk csupán. Ugyanakkor gyakorlatilag a vállalati pénzügyi döntéseket támogató mutatók, képletek egyike sem használ várható eloszlásokat vagy értéktartományokat, hanem a konkrét értékek pontos ismeretét feltételezi. Emiatt aztán használatukhoz a jövővel kapcsolatos várakozásainkat rendszerint egyetlen számba (legtöbbször a várható értékbe) sürítve kell megjelenítenünk.

E cikk azt vizsgálja, milyen eszközeink vannak arra, hogy a bemenő paraméterekkel kapcsolatos bizonytalanságot mégis meg tudjuk jeleníteni a számítások végeredményében, támogatva ezzel a kockázattudatos döntéshozatalt. Egyetértve

1 Juhász Péter habilitált docens, Budapesti Corvinus Egyetem. E-mail: peter.juhasz@uni-corvinus. hu. 
Bélyácz Iván és Daubner Katalin e lapban megjelent tanulmányának² fö üzenetével, ezek a technikák rámutatnak arra, milyen komoly jelentősége van manapság a valószínűségeknek - nemcsak a különféle pénzügyi termékek árazását végző befektetési és a kitettségeket megragadni kívánó banki területen, de a vállalati pénzügyekben is. A következőkben áttekintem a vállalati pénzügyekben leggyakrabban alkalmazott kockázatelemzési eszközöket, és - részben saját tanácsadási és oktatási tapasztalatomra építve - az azok használatával kapcsolatos buktatókat is.

\section{A VÁLLALATI MODELLEZÉS KOCKÁZATI TÉNYEZÖI}

A vállalati modellezési folyamat jó áttekintését adja Lukic (2017). Rámutat: a cégek jövőjének leírásával a szakirodalom az 1930-as évek óta foglalkozik, ám igazi lökést a fejlődésnek a számítógépek elterjedése adott. Kiemeli: a jó vállalati pénzügyi modell nemcsak (1) a számviteli összefüggéseket tükrözi helyesen, de (2) az egyes pénzügyi mennyiségek elemi összetevőkre (darab, egységár, kamat, infláció) bontását vagy visszavezetését is. Emellett (3) szükség van arra, hogy a modellezett mennyiségeket reáliákhoz (gépóra, dolgozók) kössék, amihez az adott iparág és vállalati környezet pontos ismeretére van szükség.

Vegyük észre, hogy ennek megfelelően a modellekben többféle hiba és torzítás is megjelenhet: nemcsak az egyes bemenő paraméterek pontos értékével kapcsolatban lehet bizonytalanság a modellben, de az előbb látott három összefüggésnél, különösen a legutóbbinál is. Ha tehát teljes körüen akarnánk az előrejelzési bizonytalanságot modellezni, elvileg szükség lehetne arra is, hogy ne csak egyetlen modellt vizsgáljunk eltérő bemenő paraméterekkel, de ezzel párhuzamosan többféle logikára építő modell eredményeivel is összevessük.

Ez a gyakorlatban nagyon ritkán történik meg a vállalatoknál, mert míg a bemenő adatokkal kapcsolatos bizonytalanságot egy szervezet tagjai széles körben elfogadják, a modellszerkezettel kapcsolatos bizonytalanság elismerését sokan könnyen a szaktudás hiányaként értékelhetik. Ez azért különösen érdekes, mert a bankoknál a különféle szabályozási rendszerek magától értetődőnek tartják, hogy a kitettségi modellek eltérő eredményre vezetnek, és az eredményeket a felhasznált becslési modell összetettségétől függően tekintik jobban vagy kevésbé elfogadhatónak. Sőt, egyes nézetek szerint a többféle modellre is építő, kevert rendszerek jobban teljesítenek a kockázatok megítélésénél (Mérő, 2018).

2 BÉLYÁCz IVÁN - DaubNer Katalin (2020): Logikai valószínűség, bizonytalanság, beruházási döntések. Volt-e hatása Keynes logikai valószínűségi elméletének a közgazdasági gondolkodásra? Gazdaság és Pénzügy, 7(1), 2-47. 
Más oldalról közelítve Barakonyi (1999) rámutat: különféle elörejelzési folyamataink négyféle okból is hibásak lehet. Az eredményt torzíthatja, ha 1) a környezet komplexitását nem kellő mértékben vesszük figyelembe, 2) a számszerüsítés gyenge alapokon áll, 3) modellünk nagyon érzékeny bizonyos bemenő tényezőkre, és 4) ha kifelejtjük a modellből az akaratlagosságot. Ezek közül az első és az utolsó inkább a modellválasztás kockázatára vonatkozik, míg a két középső a becslési kockázatokat fedi le (1999:82).

Beaman és társai (2005) a modellezési hibákat számszaki (kvantitatív) és minőségi (kvalitatív) hibákra bontják. Az előbbiek a mechanikai (gépelési, hivatkozási), logikai és kihagyási hibák. Az utóbbi csoport olyan hibákat takar, mint a változók értékeinek képletekbe írása hivatkozás helyett, a modell egyértelmü kezelhetőségének hiánya, a túlságosan bonyolult képletek használata, a megfelelő dokumentáció hiánya vagy a képletek és háttéradatok felülírás elleni védelmének elmulasztása.

Ha a kockázati faktorokat eredet és nem megjelenési forma szerint csoportosítjuk, 1) a modellépítés és 2) a bemenő paraméterek becslési kockázat mellett érdemes még egy kockázati tényezőre, 3) a modellezést végző szakemberre is felhívni a figyelmet. Hiába jók a logikai kapcsolatok és az inputadatok, ha a modellező nem a megfelelő modellt választotta (például túlságosan is legegyszerűsítette a valóságot). Lukic (2017) kiemeli: nem véletlen, hogy a tőzsdei elemzések szakmai minimumát sokszor a hatóságok és az olyan szakmai szervezetek is szabályozzák, mint például az okleveles pénzügyi elemzőket globálisan összefogó CFA Institute. Fontos észben tartanunk, hogy a modellező képességei és szakismerete korlátot szab annak, mennyire bonyolult folyamatokat képes elfogadható pontossággal és kellő eszköztárral modellezni.

Ezt a kockázatot jól példázza Adamczyk és Zbroszczyk (2017) vizsgálata. Az általuk elemzett 224 lengyel részvényelemzés 84,7 százaléka a vállalati szabad cash flow alapú (FCFF) megközelítést használta, ám ezen elemzéseknek csupán 68 százaléka alkalmazott a szakirodalom elvárásainak megfelelően időszakonként eltérő tőkeköltséget.

Beaman és társai (2005) számvitelszakos egyetemistákat vizsgálva rámutatnak: a külön ilyen képzésben nem részesülő diákok között a táblázatkezelő programokban elkövetett különféle modellezési hibák, azok között is a tervezési hibák igen gyakoriak. Ugyanakkor ezek előfordulása lényegesen csökkent már egyetlen félévnyi modellezési kurzus hallgatása után is. A gyakorlati oktatás fóként a lényeges elemek kifelejtésének, a felesleges duplikációknak és a hivatkozás helyetti fix értékek képletbe építésének előfordulását tudta csökkenteni.

Az emberek elhagyása a folyamatból (például mesterséges intelligenciával való helyettesítésük) azonban aligha lenne jó megoldás. Lukic (2017) kiemeli, hogy a 
különféle paraméterek elörejelzésénél jól tetten érhetőek az adaptív várakozások, míg a változók közti kapcsolatok a legtöbbször heurisztikusak, robusztusok és közelítő jellegüek. Éppen ez magyarázhatja, hogy az emberek által készített modellek a szakirodalom szerint jobban teljesítenek, mint az egyszerü, egyetlen módszertanra építö, erős elméleti alapokon nyugvó statisztikai megoldások, mint például az idősorelemzés.

\section{2. ÉRZÉKENYSÉGVIZSGÁLAT ÉS FEDEZETIPONT-ELEMZÉS}

Az operációkutatás definíciója szerint „az érzékenységvizsgálat olyan elemző eljárás, amely során felderíthető, hogy milyen hatással vannak az optimális megoldásra a modell paramétereinek értékeiben bekövetkezett változások" (Ferenczi, 2006:66). Vállalati pénzügyekben ritka az optimum keresése, de a megközelítés hasonló. Az érzékenységvizsgálat során a különféle bementi paraméterek közül egyet-egyet kiválasztva azt vizsgáljuk, hogy az inputtényező változása hogyan hat egy vagy néhány eredményváltozó értékére.

Az érzékenységvizsgálat kétféle céllal készülhet. Először is az operációkutatáshoz hasonlóan vizsgálhatjuk, hogy a bemenő paraméter mekkora megváltozása kellene ahhoz, hogy a végső eredmény alapján hozott döntésünket megváltoztassuk. Ezt az alkalmazást a vállalati pénzügyek inkább fedezetipont-elemzésként ismeri (Sener-Jenkins, 2016). A másik megközelítés célja az, hogy a modell eredményét döntően befolyásoló kulcsváltozókat azonosítsuk, s ehhez azok lehetséges szélsőértékeit helyettesítjük be a modellbe.

Az érzékenységvizsgálat - szemben a később bemutatott forgatókönyv-elemzéssel - nem a modellezett stratégia kockázatát vizsgálja, hanem a bemenő paraméterek becslési hibája okozta kockázatot. Célja, hogy csökkentse az elfogadhatóan jó modellek előállítási idejét. Egy paraméter végtelenül pontos előrejelzése várhatóan végtelen sok időt és erőforrást igényel. Emiatt modellünket először durva becsléssel töltjük fel, majd az érzékenységvizsgálat eredményeit felhasználva, azon változók becslésére fordítunk nagyobb gondot, amelyek döntő szerepet játszanak a végeredmény alakításában.

Ezért az érzékenységvizsgálatot nem érdemes úgy elvégezni, hogy minden bemenő paraméternél azonos kitéréseket feltételezünk. Igen gyakori, hogy az inputváltozók várható értékét egységesen plusz-mínusz 1 vagy 10 százalékos értékkel módosítják. Ez ugyan segíthet egyfajta rugalmassági mutató becslésében, amely használható lenne további elemzésekre, de ez rendszerint elmarad. A puszta eredményhatások összevetése pedig kifejezetten hiba. A cél ugyanis nem a nyers rugalmasság vizsgálata, hiszen az egyes bemenő paramétereknek a várható érték körüli eloszlása korántsem azonos. 
A helyes megoldás az, ha az érzékenységvizsgálatnál az adott változó várható minimum- és maximumértékét helyettesítjük a modellbe, és így vizsgáljuk a hatást. Ekkor derül ki, hogy mekkora hibát ejthetünk, ha nem a helyes várható értéket használjuk. Rendszerint egyetlen elemző sem gondolja, hogy 1 százalékos elmozdulásnak ugyanakkora esélye van például a 3 százalékos várható értékű inflációnál és az 1 milliárd forintra taksált árbevételnél. Ha rákérdezünk, sokszor kiderül: az inflációt 2-4 százalék, a bevételt viszont 900-1100 millió forint közé várják. Vagyis az előbbinél +/-33 százalékos eltérést is elképzelhetőnek vélnek, míg az utóbbinál csupán +/-10 százalék a türéshatár.

Alighanem ez magyarázza a harmadik típushibát a gyakorlati alkalmazásokban. A felhasználók sokszor keverik a százalék és százalékpont jelentését, így az érzékenységvizsgálatnál 2 és 4 százalékot helyettesítenek be az inflációhoz, de 990 és 1010 millió forintot az árbevételhez. Ekkor viszont a végeredményben kapott abszolút kitérések összevetésének már alig van értelme. Ilyenkor látszik, miért is lenne jobb az alkalmazott kitérés mértékével normálni és rugalmassági mutatókat számolni.

Ezen túl Koltai (2015) arra is felhívja a figyelmet, hogy az érzékenységvizsgálat helyes elvégzési módja a modell felépítésétől is függ. Az egyszerü analitikus elemzés helyett szükség lehet a szimplex módszer alkalmazására vagy perturbációelemzésre is.

\section{FORGATÓKÖNYV-ELEMZÉS}

A forgatókönyv-elemzés során a modellbe egy-egy lehetséges jövőváltozatot jól leíró inputváltozó-kombinációt írunk be. A cél annak a vizsgálata, hogy eltérő környezetben miképpen teljesít majd az adott projekt vagy vállalat - itt tehát nem a modell, hanem a stratégia kockázatát elemezzük.

A forgatókönyv-elemzés részletes és jól használható leírását adja Barakonyi (1999, 3. fejezet). A szerző aláhúzza: ez a módszer olyan forgatókönyvek kidolgozását követeli meg, amelyek többek között 1) lehetséges jövőállapotokat írnak le 2) konzisztensen és 3) hihetően, miközben 4) alternatívákat jelentenek, s 5) viszonylag magas bekövetkezési valószínüségüknek köszönhetően a kidolgozott 2-4 forgatókönyv lefedi a várható események döntő részét.

E megközelítésben számos eltérő hátterű vállalati szakember bevonásával például ötletroham segítségével érdemes feltérképezni a vállalati jövő lehetséges eseményeit, majd a néhány legvalószínübb irányt forgatókönyvvé fejleszteni. Az alacsony bekövetkezési valószínüségük miatt a forgatókönyvekbe be nem került eshetőségeket sem szabad elvetni: ezekre a vállalati kockázatkezelésnek kell tudatosan felkészülnie. 
A szcenárióelemzés során tehát szó sem lehet a gyakorlatban olyannyira elterjedt „optimista”, „normál” és „pesszimista” forgatókönyvekről (Lukic, 2017). Olyan gazdasági helyzet (extrém kimenet) ugyanis nemigen fordulhat elö, amikor minden, a terv szempontjából kritikus paraméter a legelőnytelenebb vagy éppen a legkedvezőbb értékét veszi fel. Az ilyen helyzetek nemcsak ritkák, de az esetek többségében nem is lehetségesek és konzisztensek: ha számunkra elönyösen a gazdaság fellendül és a kereslet megugrik, nekünk hátrányosan a piaci verseny erösödik, és a bérek is növekedni kezdhetnek. A szcenáriók kidolgozása során tehát figyelembe kell vennünk a paraméterek szokásos együttmozgását és a gazdasági logikát is.

Természetesen a forgatókönyvek kidolgozása és modellbe helyettesítése után a legtöbbször kiderül, mikor járunk a legjobban, vagyis melyik eset az optimista. Ezen a ponton azonban már aligha érdemes átkeresztelni a forgatókönyveket, amelyeket létrehozásukkor inkább az általuk leírt piaci és belső folyamatok alapján célszerű elnevezni.

Szintén hiba, ha a szcenáriókat diszkrét alternatívák helyett alkalmazzuk: ha a két vizsgált eset például csak a következő években értékesített mennyiségekben tér el, akkor az inkább több periódusos érzékenységvizsgálat, semmint szcenárióelemzés. Az ilyen számítások ugyanakkor nagyon fontosak, csak éppen egy konkrét forgatókönyv elemzése során kell bevetni azokat.

Tévedésekhez vezethet azt is, ha a kidolgozott forgatókönyvek között a teljes eseményteret felosztjuk. Három-négy alternatíva aligha írja le a valóságot; ha azonban nem hagyunk teret az extrém eseményeknek és értékeknek, könnyen elfeledkezhetünk a megfelelő kockázatkezelésről. Ha valamiért mégis a teljes valóság leírására törekszünk csupán néhány esettel, akkor ügyelni kell arra, hogy a kezelt esetekben együttesen minden bemenő paraméternek a valóságban várt teljes értékkészlete és eloszlása megjelenjen.

\section{MONTE-CARLO-SZIMULÁCIÓ}

A Monte-Carlo-szimuláció lényege az, hogy a megfelelően kiválasztott bemeneti változókra - az adott forgatókönyv mellett érvényes eloszlási jellemzőik alapján - egyenként egyedi realizációt generál, majd a kapott kombinációt a modellbe helyettesítve, rögzíti az eredményváltozók értékeit. A folyamot sokszor (általában legalább tízezerszer) megismételve az eredményváltozók puszta várható értéke helyett már azok eloszlása is előre jelezhető és elemezhető. Ugyanakkor, mivel ehhez az eljáráshoz több paramétert kell megbecsülnünk, a bemenő adatok pontosságából származó kockázat magasabb lehet, így könnyen lehetnek eredményeink torzítottak. 
A Barakonyi (1999:82) által megjelölt négyféle modellezési hibára a gyakorlatban sajnos itt is könnyü példát találni. Nem ritkák a mindössze két-három változó értékét ötletszerű normális eloszlás alapján módosító Monte-Carlo-szimulációk, a nem helyesen megválasztott eloszlásformák (negatív részvényértékre vezető kalkulációk) vagy az elvárt hozamtól tartósan elmaradó nyereségesség mellett is örökös müködést feltételező cégértékelési modellek.

Az ilyen feladatoknál gondolnunk kell arra is, hogy a bemeneti változóink eloszlását az adott környezetben mennyire jól tudjuk leképezni. A szimulációknál felhasznált folytonos eloszlások - a megfigyeléseink és az adott számítógépes alkalmazás korlátaihoz igazodva - a legtöbbször szimmetrikusak. McLeay és Azmi (2000) arra hívja fel a figyelmet, hogy a különféle pénzügyi mutatók szokásos képletei sokszor inkább aszimmetrikus, ferde és csúcsos eloszlásokat produkálnak, ezért célszerü lehet, ha azokat transzformájuk, mert az ezekre építo, kategorizáló modellek a legtöbbször érzékenyek a normalitás megsértésére. Eredményeik szerint megoldásuk hatékonyabb a különféle extrém értékek elhagyásánál, mivel több információtartalom marad elérhető.

$\mathrm{Az}$ is előfordulhat, hogy a helyes eloszlásokat nekünk magunknak kell létrehoznunk, mert a kiválasztott táblázatkezelőben erre nincsen beépített eszköz. Linares-Mustarós és társai (2013) például a legtöbb programban közvetlenül nem elérhető fuzzy logika alkalmazását javasolják a várható vállalati likviditási nehézségek megbecslésére. Rámutatnak: ez a megközelítés a gyakorlatban is jól használható becslést ad a fizetési nehézségek felmerülési gyakoriságára, és némi tanulással a gondolkodásmód könnyen adaptálható a vállalati területen széles körben alkalmazott táblázatkezelő programok modelljeiben is.

Wang és társai (2010) ugyanakkor azt emelik ki, hogy önmagában a Monte-Carlo-szimuláció sem lehet gyógyír mindenre. A hagyományos szimuláció eredményei jellemzően csak nagyon keveset árulnak el a szélsőséges (kis valószínűségű) eseményekről, ráadásul az egyes kimeneteknél a befolyásoló tényezők parciális hatása is csak nehezen fejthető vissza. Az általuk javasolt kiegészítő számítási megoldás a Monte-Carlo-szimuláció számítási igényének jelentős növelése nélkül segít e hiányosságok orvoslásában. Hasonló hazai gyakorlati alkalmazásra utalnak Fiáth és társai (2013) is.

A kockázatelemzésnek számos más alternatív megközelítése is van. Például $L i$ és társai (2018) szerint csak a többszintű fuzzy logikát kvantitatív elemzéssel kombinálva lehet a vállalati pénzügyi kockázatokat jól megragadni. Egyidőben alkalmaztak szubjektív és objektív rangsorokat, majd TOPSIS-módszerrel öszszefésülték azokat. Nowak (2005) ugyanakkor beruházási projektek értékeléséhez a kvalitatív és kvantitatív információkat egyidejűleg feldolgozó Promethee II módszert javasolja szimulációs eredmények és sztohasztikus dominanciaelvek kombinálásával, amelyeket szakértői minősítésekkel is kiegészített. 
Lehet, hogy az ilyen megközelítések pontosabb eredményt nyújtanak laboratóriumi körülmények között, ám hétköznapi alkalmazásukhoz korántsem elegendő sem a szokásos szakirányú alapképzéseken elsajátítható ismeretanyag, sem a vállalati környezetekben rendszerint elérhető szoftvertámogatás. Így az ilyen és hasonló kutatások csak a modellkiválasztással kapcsolatos bizonytalanságot csökkentik, miközben a bemenő adatokból és a modell felhasználóiból adódó kockázatokat akár növelhetik is.

\section{5. ÖSSZEGZÉS}

A pénzügyi modellezési folyamatban három kockázati forrást is azonosíthatunk. A hiba eredhet a modellező személyéből (kellő ismeretek és erőforrások hiánya, motivációs és etikai kérdések), a modell sajátosságaiból (téves vagy leegyszerüsítő feltevések és összefüggések), valamint a bemenő paraméterek értékeinek hibás becsléséből is. A szokásos kockázatelemzési eszközök csak ez utóbbi hibaforrásra koncentrálnak, de egy jó vállalati kockázatkezelési rendszernek mindhárom faktor hatását célszerü mérsékelni például egymás munkáját ellenőrizni képes elemzőcsapat kialakításával, alternatív modellek párhuzamos használatának az elöírásával és folyamatos továbbképzéssel.

A cikk a modellek kockázatait mérséklő eszközök közül részletesen az érzékenységvizsgálatot, a forgatókönyv-elemzést és a Monte-Carlo-szimulációt vizsgálta. Miközben a módszerek magyar nyelven is jól dokumentáltak, sajnos nem ritka, hogy alkalmazásukba hiba csúszik.

De a szakirodalom arra is rámutat, hogy legegyszerübb formájukban nem feltétlenül vezetnek a legjobb eredményre. Ugyanakkor a valóságot jobban leíró, komplex modellek érzékenyebbek lehetnek a bemenő adatok becslési pontosságára (esetleg csak nagyon nehezen elérhető adatokat igényelhetnek), és speciális kihívást támaszhatnak a modellezők személyével kapcsolatban is. Emiatt alkalmazásuk akár növelheti is a modellezés összesített kockázatát. 


\section{HIVATKOZÁSOK}

Adamczyk, Piotr - Zbroszczyk, Agnieszka (2017): Business Valuation - Practice of domestic WSE members in 2016. Zeszyty Naukowe Uniwersytetu Szczecińskiego. Finanse, Rynki Finansowe, Ubezpieczenia, 89(5), 233-249, DOI: 10.18276/frfu.2017.89/2-17.

Barakony Károly (1999): Stratégiai tervezés: Stratégiaalkotás I. Budapest: Nemzedékek Tudása Tankönyvkiadó, 240 p.

Beaman, Ian - Waldmann, Erwin - Krueger, Peter (2005): The Impact of Training in Financial Modelling Principles on the Incidence of Spreadsheet Errors. Accounting Education, 14(2), 199-212, DOI: 10.1080/0963928042000229699.

Ferenczi Zoltán (2006): Operációkutatás. Győr: Széchenyi István Egyetem, , http://www.sze. hu/ kundi/opkut_jegyzetek/Oper\%Eıci\%F3kutat\%E1s.pdf (letöltve: 2020. január 19.).

Fiáth Attila - Nagy Balázs - Tóth Péter - Dóczi Szilvia - Dinya Mariann (2013): Egységes kockázatkezelési módszertan kialakítása a villamosenergia-ipari átviteli rendszerirányító társaságnál. Vezetéstudomány, 44(1), 49-62.

Koltai Tamás (2015): Érzékenységvizsgálat termeléstervezési és termelésütemezési modelleknél. MTA Nagydoktori értekezés, http://real-d.mtak.hu/778/ (letöltve: 2020. január 19.).

Li, Dan-Ping - Cheng, Si-Jie - Cheng, Peng-Fei - Wang, Jian-Qiang - Zhang, Hong-Yu (2018): A Novel Financial Risk Assessment Model for Companies Based on Heterogeneous Information and Aggregated Historical Data. PLoS ONE 13(12), 1-25. DOI:10.1371/journal.pone.0208166.

Linares-Mustarós, Salvador - Ferrer-Comalat, Joan Carles - Cassú Serra, Elvira (2013): The assessment of cash flow forecasting, Kybernetes, 42(5), 720-735. DOI: 10.1108/K-03-2013oo6o.

Lukic, Zoran (2017): The Art of Company Financial Modelling. Croatian Operational Research Review 8(2), 409-27. DOI: http://hrcak.srce.hr/crorr?lang=en.

McLeay, Stuart - Azmi, Omar (200o): The Sensitivity of Prediction Models to the Non-Normality of Bounded and Unbounded Financial Ratios. The British Accounting Review 32(2), 213-30. DOI: 10.1006/bare.1999.0120.

MéRő KATALIN (2018): A kockázatalapú bankszabályozás előretörése és visszaszorulása - Az ösztönzési struktúrák szerepe. Közgazdasági Szemle, 65 október, 981-1005. DOI: 10.18414/ KSZ.2018.10.981.

NowaK, Maciej (2005): Investment Projects Evaluation by Simulation and Multiple Criteria Decision Aiding Procedure. Journal of Civil Engineering \& Management 11(3), 193-202. DOI: 10.1080/13923730.2005.9636350.

Sener, Salci - Jenkins, Glenn P. (2016): Incorporating Risk and Uncertainty in Cost-Benefit Analysis. Development Discussion Papers, http://search.ebscohost.com/login.aspx?direct=true $\& \mathrm{db}=$ edsrep\&AN=edsrep.p.qed.dpaper.291\&site=eds-live.

Wang, Yu - Cao, Zijun - Au, Siu-Kui (2010): Efficient Monte Carlo Simulation of Parameter Sensitivity in Probabilistic Slope Stability Analysis. Computers and Geotechnics 37(7-8), 1015-22. DOI: 10.1016/j.compgeo.2010.08.010. 